\title{
Faculty's work engagement in patient care: impact on job crafting of the teacher tasks
}

Joost W. van den Berg ${ }^{1 *}$ D, Christel P. M. Verberg ${ }^{2}$, Albert J. J. A. Scherpbier ${ }^{3}$, A. Debbie C. Jaarsma ${ }^{4}$, Onyebuchi A. Arah ${ }^{5}$ and Kiki M. J. M. H. Lombarts ${ }^{1}$

\begin{abstract}
Background: High levels of work engagement protect against burnout. This can be supported through the work environment and by faculty themselves when they try to improve their work environment. As a result, they can become more engaged and better performers. We studied the relationship between adaptations by physicians to improve their teaching work environment, known as job crafting, and their energy levels, or work engagement, in their work as care provider and teacher. Job crafting encompasses seeking social (i) and structural (ii) resources and challenges (iii) and avoiding hindrances (iv).

Methods: We established a cross-sectional questionnaire survey in a cohort of physicians participating in classroom and clinical teaching. Job crafting and work engagement were measured separately for physicians' clinical and teaching activities. We analyzed our data using structural equation modelling controlling for age, gender, perceived levels of autonomy and participation in decision making.
\end{abstract}

Results: 383 physicians were included. Physicians' work engagement for patient care was negatively associated with two job crafting behaviors in the teaching roles: seeking structural resources (classroom teaching: $\beta=-0.220$ [95\% Cl: -0.319 to -0.129$]$; clinical teaching: $\beta=-0.148$ [95\% Cl: -0.255 to -0.042 ]); seeking challenges (classroom teaching: $\beta=-0.215$ [95\% Cl: -0.317 to -0.113 ]; clinical teaching:; $\beta=-0.190$ [95\% Cl: -0.319 to -0.061$]$ ). Seeking social resources and avoiding hindrances were unaffected by physicians' work engagement for patient care.

Conclusions: High engagement for teaching leads to job crafting in teaching. High engagement for patient care does not lead to job crafting in teaching.

Keywords: Work engagement, Job crafting, Career development, Faculty development, Clinical teaching

\section{Background}

Faculty's burnout is a major concern for the quality of clinical training, affecting students, residents and clinical faculty alike [1-4]. The negative effects of burnout include absenteeism from work, poor health and poor performance. Work engagement has been established as a positive opposite of burnout [5], within the framework provided by the Job Demands-Resources model [6]. Demands and resources refer to those work and personal characteristics which influence well-being at work. Under the right circumstances, resources boost positive well-being, or engagement, whereas demands drive negative well-being,

\footnotetext{
* Correspondence: j.w.vandenberg@amc.uva.nl

${ }^{1}$ Professional Performance research group, Department of Medical

Psychology, Academic Medical Center (AMC-UvA), Meibergdreef 15, 1105AZ

Amsterdam, the Netherlands

Full list of author information is available at the end of the article
}

or burnout [7]. It has been argued and evidenced that an increase in work engagement has a preventive effect on burnout [5], while increasing or maintaining performance in patient care [8] and teaching [9]. Table 1 highlights the commonalities and differences between burnout and work engagement $[5,10,11]$. Institutions can enable their clinical faculty to become engaged by providing a supportive work environment consisting of known job resources, such as ensuring the right amount of autonomy and enough participation in decision making [12].

There is currently a gap in the literature on what clinical faculty do themselves to ensure they become or stay engaged. This knowledge will help us further understand how to guide them in these activities, in addition to what is known about how to optimize their work environment. From other contexts we know professionals shape their

(c) The Author(s). 2018 Open Access This article is distributed under the terms of the Creative Commons Attribution 4.0 International License (http://creativecommons.org/licenses/by/4.0/), which permits unrestricted use, distribution, and 
Table 1 Commonalities and differences between burnout and work engagement

\begin{tabular}{|c|c|c|c|}
\hline Characteristic & Burnout & Work engagement & Meaning \\
\hline Level of activation & Exhaustion or low activation & Vigor or high activation & $\begin{array}{l}\text { Burnout and work engagement } \\
\text { represent ends of the activation } \\
\text { spectrum }\end{array}$ \\
\hline Level of identification & Cynicism or low identification & Dedication or high identification & $\begin{array}{l}\text { Burnout and work engagement } \\
\text { represent ends of the } \\
\text { identification spectrum }\end{array}$ \\
\hline Level of efficacy & Low efficacy & No opposite or equivalent & $\begin{array}{l}\text { Burnout is associated with low } \\
\text { levels of personal accomplishment }\end{array}$ \\
\hline Level of absorption & No opposite or equivalent & High absorption & $\begin{array}{l}\text { Work engagement is associated } \\
\text { with high levels of concentration } \\
\text { and engrossment }\end{array}$ \\
\hline Summary of relationship: & \multicolumn{3}{|c|}{$\begin{array}{l}\text { Demands in work (e.g. time pressure) increase the risk of burnout. Resources in work (e.g. perceived autonomy) } \\
\text { help overcome these demands and drive work engagement. When vigor and dedication are high, a buffer } \\
\text { towards exhaustion and cynicism is maintained. High absorption additionally helps to perform well. (A. B. Bakker, } \\
2011 \text { b; Maslach et al., 2001; Schaufeli, Salanova, González-Romá, \& Bakker, 2002b) }\end{array}$} \\
\hline
\end{tabular}

work environment on their own, to meet their needs and preferences in the perceived job demands and resources, called job crafting [13]. Job crafting leads professionals to be more engaged in their work and ultimately perform better [13-17]. Job crafting covers four strategies: (i) seeking social resources, (ii) seeking structural resources, (iii) seeking challenges or (iv) avoiding hindering demands. As such, job crafting involves changing both content of work as well as the work environment.

Crafting ones job is especially relevant for clinical faculty. Their concurrent responsibilities in patient care and teaching (in addition to any other responsibilities such as in research) require clinical faculty to find a balance in the various roles - under increasing expectations to perform highly in all roles [18]. A risk for burnout arises when faculty cannot spend enough time in the role most meaningful to them [2] or feel unsupported for either role [19]. However, for some faculty working in both roles may serve as a welcome change in pace, giving them energy and offering challenges, possibly leading to engagement to their work [20].

Clinical faculty experience different levels of work engagement in the roles of care provider and teacher; in general, physicians seem most engaged with patient care [9]. As a consequence, they work more energetically and more concentrated in patient care than in teaching. It may not necessarily mean faculty invest this energy in their teaching-role as well. Since faculty engaged to their work as care provider are not necessarily seen as better clinical teachers by residents [9], it remains uncertain if patient care work engagement leads to job crafting in teaching.

Theory does predict an intra-role effect between work engagement and job crafting: patient care work engagement will lead to job crafting within patient care practice [14]. What remains unknown is the inter-role effect: whether or not patient care work engagement additionally leads to job crafting in teaching, i.e. whether or not clinical faculty will invest any high levels of energy from patient care work into shaping their teaching work. This insight will help understand how clinical faculty find a balance between patient care and teaching and what institutions may contribute in this process. This may translate into policies and individual initiatives to create a better balance between roles and could provide coaches, faculty developers and similar mentor-like staff with better tools to aid faculty in their work.

To understand the relations between work engagement, job crafting and combining patient care with teaching, we chose to distinguish between classroom and clinical teaching to acknowledge the different settings in which both occur. Clinical teaching and patient care are often provided simultaneously whereas clinical faculty remove themselves from the clinical workplace to classrooms or lecture halls for 'regular' classroom teaching. We investigated two related research questions:

1) What is the impact of work engagement on job crafting within faculty's roles in patient care, classroom teaching and clinical teaching? (Fig. 1).

2) What is the impact of patient care work engagement on job crafting in classroom teaching and clinical teaching practices, as an across roles effect? (Fig. 2) To answer both questions, we established a cross-sectional multi-center questionnaire survey in a cohort of clinical faculty combining patient care delivery with either classroom teaching or clinical teaching. For the separate activities of patient care, clinical teaching and classroom teaching, we assessed faculty's work engagement and job crafting behaviors through validated instruments. We examined the relationship between work engagement 


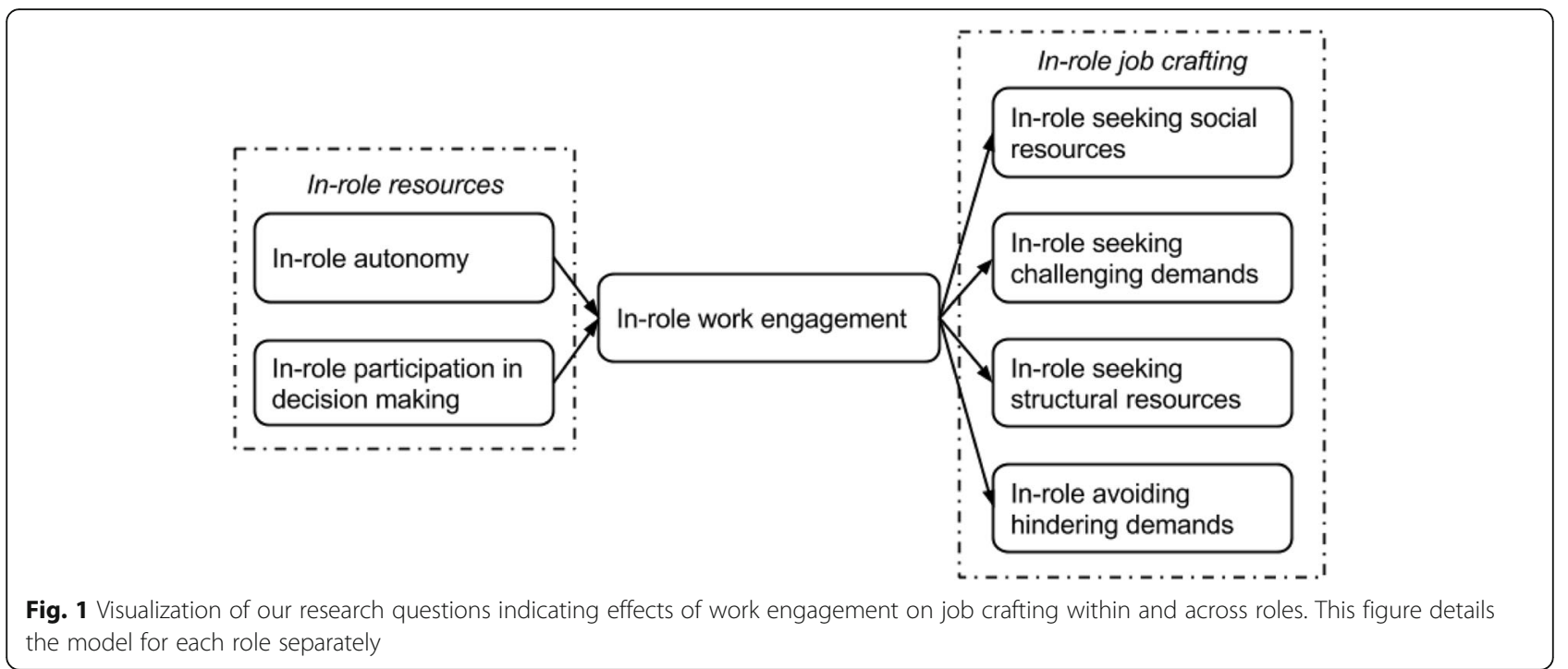

and job crafting within and across patient care, classroom teaching and clinical teaching.

\section{Methods}

\section{Design}

We established a cohort of physicians participating in classroom teaching and clinical teaching and used an online questionnaire containing validated measures to quantify well-being, job crafting and additional variables.

\section{Setting and participants}

In the Netherlands, all hospital physicians are expected to play an active role in teaching residents and interns (undergraduate students in the final three years of their six-year medical studies). Equally, residents are expected to actively participate in clinical teaching to interns. Both faculty and residents were included in our sample. Physicians at university teaching hospitals often also participate in undergraduate or bachelor level medical education, which typically involves classroom teaching.
Lastly, especially in university teaching hospitals but generally in any teaching hospital as well, physicians participate in research to a certain extent.

Five academic medical centers and nine non-academic teaching hospitals from across the Netherlands participated in this study. Invitations for participation were sent by email, in which confidentiality was guaranteed and additional information was presented. Where possible a direct email was sent to physicians and university faculty, otherwise invitations were sent through snowballing to volunteers via administrators, course directors or secretarial offices. Data collection took place between February and August 2015.

\section{Ethics}

Ethical approval was obtained through the Dutch Association for Medical Education Ethical Review Board under dossier number 385. Participant consent was written (in digital form) and without consent participation in the online survey was impossible.

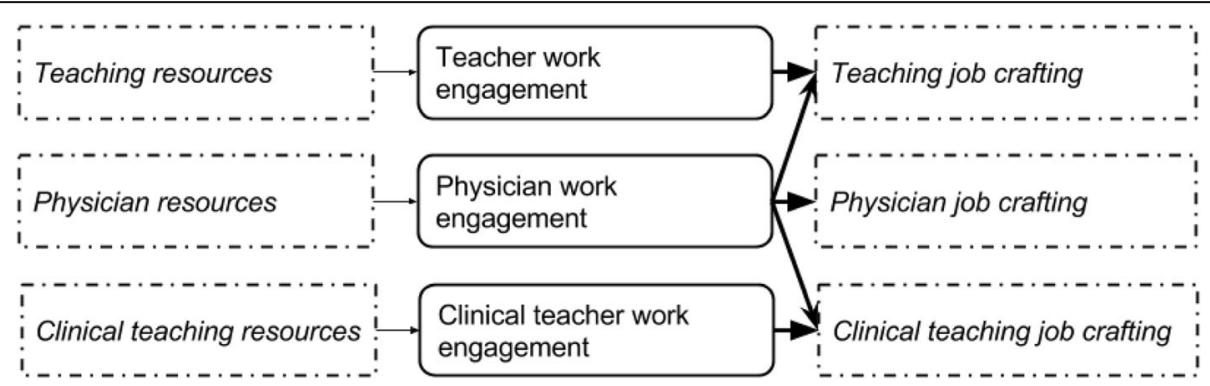

Fig. 2 Visualization of our research questions indicating effects of work engagement on job crafting within and across roles. This model details the suggested relationship between roles with the resources and job crafting subscales displayed in a condensed way 


\section{Questionnaires and predictive measures}

A digital questionnaire was developed centered around three validated measures: the job crafting questionnaire [21], the work engagement questionnaire (UWES-9) [22] and a scale for the perceived job resources autonomy and participation in decision making [23]. These measures have been validated in different contexts, occupations, and cultures. In addition, they have previously been used in health care and education research specifically $[9,15,24]$. In total, these measures encompass 37 questions and participants were asked to fill out all questions for two or three of their professional roles depending on their work responsibilities at that time: classroom teacher, clinical teacher and patient care provider.

The main predictor was defined as the mean score on the UWES-9 questionnaire. The UWES-9 includes statements on the participant's well-being and its nine items are rated on a zero to six scale representing 'never' to 'always/ daily'. An example statement is: "My work inspires me." The statements cover feelings arising from and attitudes towards work and cover all three dimensions of work engagement (vigor, dedication and absorption).

The UWES-9 scores were in turn predicted by the mean score on the autonomy and participation in decision making scales. The autonomy-scale consists of three items. An example question is: "Can you decide on your own how to do your work?" The participation in decision making scale consists of four items. An example statement is: "I have a sufficient say in the working schedule." The job resourcescales are rated on a regular five-point Likert scale, representing 'never' (1) to 'often' (5).

\section{Outcome measures: Job crafting}

The main outcomes were defined as the mean scores on the four subscales of the job crafting questionnaire. Twenty-one statements cover the four subscales: (i) strengthening either social (five items) or (ii) structural resources (five items) in work, (iii) seeking challenges (five items) or (iv) the avoidance of hindering demands (six items). Example statements for each subscale are respectively: (i) "I ask others for feedback on my job performances.", (ii) "I try to develop my capabilities.", (iii) "If there are new developments, I am one of the first to learn about them and try them out." and (iv) I make sure that my work is mentally less intense. The job crafting questionnaire is self-rated on a regular five-point scale and represents job crafting on a 'never' (1) to 'often' (5) basis. The statements cover tendencies and actual behaviors but do not address perceived success in job crafting.

\section{Covariates}

Age and gender were added to the analysis to correct for possible confounding. The need to include hospital as covariate was tested based on the intra-class correlation.
To account for differences between university teaching hospitals (UTH) and general teaching hospitals (GTH) such as time allocated for teaching, this covariate was additionally included as binary variable in the analyses to correct for confounding.

To account for differences in needs and perceptions towards work engagement and job crafting, this covariate was additionally included as binary variable in the analyses to correct for confounding. Additionally, ANOVA was conducted on the work engagement and job crafting scores to determine whether both groups differed in mean values.

\section{Statistical analysis}

We chose path analysis with structural equation modeling (SEM) to allow for simultaneous assessment of the interrelations between job resources, work engagement and job crafting within and across roles, given other variables.

We calculated Cronbach's alpha on all scales and subscales separately as measure of reliability in our specific sample. The preparation for conducting the structural equation modeling then consisted of defining the structural model based on theory and our research question and resulted in the conceptual framework (Figs. 1 and 2) presented in the introduction. Subsequently, we checked the assumptions of normality, for outliers and for co-linearity and correlations between specified variables. For final variable selection, we calculated the intra-class correlation of the hospital variable to inform inclusion. The outcomes were corrected for age, gender, UTH versus GTH and medical specialist versus resident. We first performed our analysis with full-cases only and subsequently with multiple imputation using multivariate imputations by chained equations to deal with missing data. We used 50 imputations with 200 iterations based on the column with the highest percentage of missing data [25]. We used predictive mean matching for all columns. We bootstrapped the standard errors using 10,000 draws on complete cases only. We used the robust maximum-likelihood estimation method in the analysis as well as weighted least square estimation of mean and variance. The latter was used a sensitivity analysis to assess whether work engagement and job crafting would have a different relationship if these variables were to be considered ordered categorical variables. The results did not change when using weighted least square estimations of mean and variance. The relations between the predictors and outcomes in terms of their effect direction and size were reported using standardized coefficients with $95 \%$ confidence intervals.

Fit measures were calculated, but models were not re-specified based on these measures as our intent was to study specific path coefficients rather than analyzing full models. 
R 3.2.3 [26] was used to prepare data and the lavaan-package [27] was used to handle the SEM analysis. The semTools [28] and mice [29] packages were used for imputation and analysis of missing data.

\section{Results}

\section{Demographics}

In total, 1072 participants representing 14 teaching hospitals started answering the questionnaire and gave informed consent, an additional 17 did not provide informed consent whose data were thus not included in our final database. Response per center ranged from 8 to 193; exact response rates were incalculable because of uncertainty about the exact extent of the teaching staff at most participating centers. Based on local estimations of the extent of the teaching staff and our responses, response was at most $20 \%$.

Out of the 1072 participants, 507 reported that their most time consuming role, besides (classroom or clinical) teaching, was patient care (other options were research and management (which were mostly a secondary role) or teaching only). Out of these 507, 419 filled out the entire questionnaire and 383 of these were physicians, resulting in 383 measures for patient care work engagement and job crafting, 303 for classroom teaching and 347 for clinical teaching (Fig. 3). Excluded participants were full-time researchers, teachers or otherwise not involved with patient care. Full sample details and descriptive statistics are provided in Table 2.

Individual hospitals were not included as a variable in our final model because the confidence interval of the intra-class correlation (ICC) for all measures (except for autonomy as classroom teacher) was covering zero (i.e. the lower bounds were negative and upper bounds positive), indicating no influence from location. Cronbach's alpha's of all measures used ranged from 0.64 (for job crafting structural resources in patient care) to 0.92 (for work engagement in classroom teaching). We consider these reliability levels moderate to very good.

\section{Intra-role impact of work engagement on job crafting}

Clinical faculty experience different levels of work engagement in the roles of care provider and teacher. The mean level of work engagement for patient care was 4.24 (on a 0 to 6 scale), for clinical teaching 3.93 and classroom teaching 3.78. Tables 3 and 4 show correlations between engagement for patient care, classroom teaching (Table 3) and clinical teaching (Table 4) and job crafting (JC) in these roles. First, regarding the intra-role effects, there was a consistent positive effect of work engagement on JC subscale 'seeking structural resources,' 'social resources and challenges' within roles. Within classroom teaching, the strongest effect was found when classroom teaching was combined only with patient care (and not also classroom teaching), for 'seeking of structural resources' ( $\beta=0.480$, 95\% CI: 0.126 to 0.834 ). There was a minor negative effect of classroom teacher work engagement on the JC subscale 'avoidance of hindering demands in classroom teaching' $(\beta=-0.062$, $95 \%$ CI: -0.105 to -0.019 , for clinical faculty combining both teaching roles with patient care). Within clinical teaching, the strongest effect was found when clinical teaching was combined only with patient care (and not also classroom teaching), again for the JC domain 'seeking structural resources' ( $B=0.379 .95 \% \mathrm{CI}$ : 0.252 to 0.506). There was again a minor negative effect of clinical teacher work engagement on 'avoidance of hindering demands in clinical teaching' ( $\beta-0.056,95 \%$ CI: -0.099 to

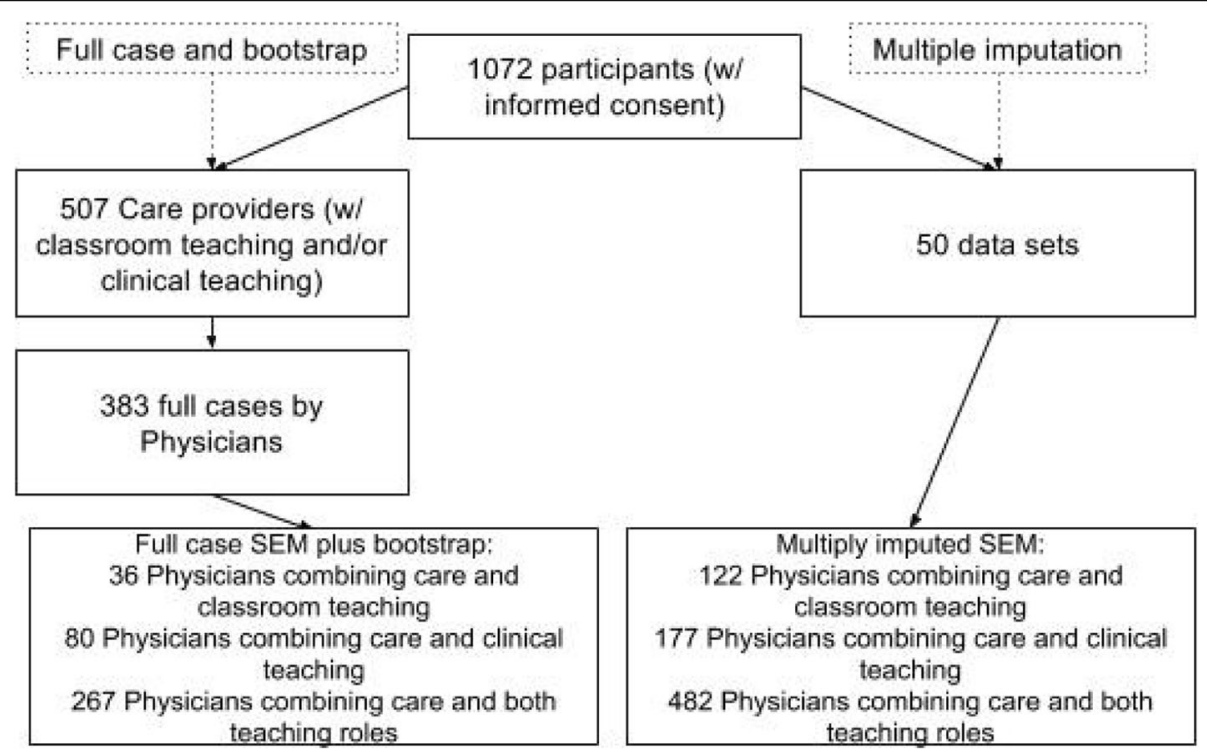

Fig. 3 Sample flow chart and data handling 
Table 2 Sample characteristics and descriptive statistics ( $N=383)$ A: other includes f.e. full professors, B: other includes f.e. specialized outpatient clinics, C: other includes f.e. primary care physicians

\begin{tabular}{|c|c|c|c|c|}
\hline Gender & 185 male (48.3\%) and 198 (51.7\%) female & & & \\
\hline Age, in years & 26-67 (median: 42.00) & & & \\
\hline Employed as medical specialist / resident / other $^{\mathrm{A}}$ & $255(66.6 \%) / 117$ (30.5\%) / 11 (2.9\%) & & & \\
\hline $\begin{array}{l}\text { Employed at university teaching hospital (UTH) / } \\
\text { general teaching hospital (GTH) / } \text { other }^{\mathrm{B}}\end{array}$ & $177(46.2 \%) / 183(47.8 \%) / 23(6.0 \%)$ & \multirow[t]{2}{*}{$\begin{array}{l}\text { Range per } \\
\text { hospital 7-60 }\end{array}$} & & \\
\hline $\begin{array}{l}\text { Primary teaching role in classroom teaching / } \\
\text { clinical teaching / both }\end{array}$ & $36(9.4 \%) / 80$ (20.9\%) / 267 (69.7\%) & & & \\
\hline $\begin{array}{l}\text { Working in surgical specialty / medical specialty } \\
\text { / diagnostic or other }\end{array}$ & 99 (25.8\%) / 145 (37.9\%) / 139 (36.3\%) & & & \\
\hline Variable & Role & $\begin{array}{l}\text { Sample } \\
\text { mean (SD) }\end{array}$ & $\begin{array}{l}\text { Medical specialist } \\
\text { mean }(\mathrm{SD})(N=255)\end{array}$ & $\begin{array}{l}\text { Resident mean } \\
\text { (SD) }(N=117)\end{array}$ \\
\hline \multirow[t]{3}{*}{ Work engagement } & Patient care & $4.24(0.90)$ & $4.26(0.94)$ & $4.25(0.80)$ \\
\hline & Clinical Teaching & $3.93(0.97)$ & $4.05(0.92)$ & $\begin{array}{l}3.64(1.06) \\
(p<0.001)\end{array}$ \\
\hline & Classroom Teaching & $3.78(1.07)$ & $3.80(1.09)$ & $3.71(1.04)$ \\
\hline \multirow[t]{3}{*}{ Job Crafting - Seeking structural Resources } & Patient care & $4.02(0.50)$ & $3.97(0.51)$ & $\begin{array}{l}4.11(0.49) \\
(p=0.01)\end{array}$ \\
\hline & Clinical Teaching & $3.41(0.63)$ & $2.21(0.59)$ & $\begin{array}{l}2.48(0.66) \\
(p<0.001)\end{array}$ \\
\hline & Classroom Teaching & $3.29(0.68)$ & $3.24(0.66)$ & $3.33(0.69)$ \\
\hline \multirow[t]{3}{*}{ Job Crafting - Seeking social Resources } & Patient care & $2.64(0.77)$ & $2.34(0.60)$ & $\begin{array}{l}3.37(0.66) \\
(p<0.001)\end{array}$ \\
\hline & Clinical Teaching & $2.30(0.62)$ & $3.46(0.61)$ & $\begin{array}{l}3.19(0.63) \\
(p<0.001)\end{array}$ \\
\hline & Classroom Teaching & $2.26(0.66)$ & $2.03(0.55)$ & $\begin{array}{l}2.68(0.70) \\
(p<0.001)\end{array}$ \\
\hline \multirow[t]{3}{*}{ Job Crafting - Seeking challenges } & Patient care & $2.89(0.65)$ & $2.89(0.63)$ & $2.89(0.71)$ \\
\hline & Clinical Teaching & $2.51(0.72)$ & $2.55(0.70)$ & $\begin{array}{l}2.37(0.78) \\
(p<0.05)\end{array}$ \\
\hline & Classroom Teaching & $2.41(0.70)$ & $2.35(0.65)$ & $2.50(0.77)$ \\
\hline \multirow[t]{3}{*}{ Job Crafting - Avoiding hindrances } & Patient care & $1.49(0.46)$ & $1.44(0.40)$ & $\begin{array}{l}1.58(0.53) \\
(p<0.01)\end{array}$ \\
\hline & Clinical Teaching & $1.43(0.44)$ & $1.42(0.40)$ & $1.44(0.45)$ \\
\hline & Classroom Teaching & $1.45(0.47)$ & $1.43(0.47)$ & $1.49(0.46)$ \\
\hline \multirow[t]{3}{*}{ Autonomy } & Patient care & $3.28(0.84)$ & $3.52(0.77)$ & $\begin{array}{l}2.70(0.72) \\
(p<0.001)\end{array}$ \\
\hline & Clinical Teaching & $3.37(0.85)$ & $3.54(0.79)$ & $\begin{array}{l}2.86(0.81) \\
(p<0.001)\end{array}$ \\
\hline & Classroom Teaching & $3.14(0.93)$ & $3.28(0.97)$ & $\begin{array}{l}2.84(0.81) \\
(p<0.001)\end{array}$ \\
\hline \multirow[t]{3}{*}{ Participation in Decision Making } & Patient care & $3.35(0.90)$ & $3.62(0.83)$ & $\begin{array}{l}2.71(0.72) \\
(p<0.001)\end{array}$ \\
\hline & Clinical Teaching & $3.22(1.00)$ & $3.48(0.90)$ & $\begin{array}{l}2.45(0.86) \\
(p<0.001)\end{array}$ \\
\hline & Classroom Teaching & $3.00(0.97)$ & $3.21(0.99)$ & $\begin{array}{l}2.53(0.80) \\
(p<0.001)\end{array}$ \\
\hline
\end{tabular}

- 0.012, for physicians combining both teaching roles with patient care).

The full results for the impact of patient care work engagement on patient care job crafting can be found in Additional file 1: Table S2. The effect of patient care working engagement on patient care job crafting was mostly positive, i.e. higher levels of work engagement were associated with increased job crafting behaviors. The strongest effect was found when participants combined work in patient care with classroom teaching only, 
Table 3 Effects of work engagement for both patient care, classroom and clinical teaching on job crafting in classroom teaching (bold indicates findings with $p<0.05$ ), full cases

\begin{tabular}{|c|c|c|c|c|}
\hline \multirow{3}{*}{$\begin{array}{l}\text { Job crafting in classroom } \\
\text { teaching }\end{array}$} & \multicolumn{2}{|c|}{ Work engagement with patient care } & \multicolumn{2}{|c|}{ Work engagement with classroom teaching } \\
\hline & \multicolumn{2}{|l|}{ Combined with... } & \multicolumn{2}{|l|}{ Combined with... } \\
\hline & $\begin{array}{l}\ldots \text { only classroom teaching } \\
(N=36)\end{array}$ & $\begin{array}{l}\text {... both teaching roles } \\
(N=267)\end{array}$ & $\begin{array}{l}\text {... only patient } \\
\text { care }(N=36)\end{array}$ & $\begin{array}{l}\text {... clinical teaching and } \\
\text { patient care }(N=267)\end{array}$ \\
\hline & Std. coef. $(95 \%$ Cl) & Std. coef. (95\% Cl) & Std. coef. $(95 \%$ Cl) & Std. coef. $(95 \%$ Cl) \\
\hline Seeking social resources & B $-0.070(-0.369-0.228)$ & B $-0.020(-0.115-0.076)$ & В $0.334(0.019-0.650)$ & В $0.137(0.058-0.215)$ \\
\hline Seeking structural resources & B $-0.123(-0.489-0.243)$ & $B-0.220(-0.319--0.120)$ & B $0.480(0.126-0.834)$ & В $0.361(0.271-0.452)$ \\
\hline Seeking challenges & B $-0 .-0.179(-0.542-0.185)$ & $ß-0.215(-0.317--0.113)$ & B $0.480(0.079-0.882$ & В $0.354(0.274-0.434)$ \\
\hline Avoiding hindrances & $\beta-0.048(-0.287-0.191)$ & B $-0.006(-0.091-0.079)$ & В $0.197(-0.060-0.454)$ & $\beta-0.062(-0.105--0.019)$ \\
\hline
\end{tabular}

for seeking challenges ( $(B=0.348,95 \%$ CI: $0.130-0.567)$. The effect of patient care work engagement on avoidance of demands was negative $(\beta=-0.127,95 \% \mathrm{CI}$ : -0.186 to -0.069 ) for clinical faculty combining work in both teaching roles with patient care.

Figure 4 summarizes the main findings from both the intra-role and inter-role effects.

\section{Inter-role impact of work engagement and job crafting}

Second, on the inter-role effects, as we studied the impact of patient care work engagement on job crafting of the teaching tasks. The effect of patient care work engage ment on classroom teaching and clinical teaching job crafting was consistently absent or negative. When clinical faculty combined patient care with both classroom and clinical teaching, there was a negative effect of being engaged for patient care on seeking structural resources and challenges in classroom teaching $(\beta=-0.220,95 \% \mathrm{CI}$ : -0.319 to -0.120 , and $\beta=-0.215,95 \%$ CI: -0.317 to 0.113 respectively) and clinical teaching $(B=-0.148,95 \%$ CI: -0.255 to -0.042 , and $\beta=-0.190$, $95 \%$ CI: -0.319 to 0.061 respectively). Being engaged for patient care did not affect the JC subscales 'seeking social resources' and 'avoiding hindrances' in neither of the two teaching roles. These findings are reported in Tables 3 and 4.
The inter-role relationship from work engagement in teaching on job crafting in patient care showed a similar pattern to vice versa relationship described in the previous paragraph. Full details can be found in Table 5. Most correlations found were negative influences from teaching work engagement on patient care job crafting, mainly for classroom teaching work engagement on seeking challenges in patient care $(\beta=-0.236,95 \%$ CI: -0.398 to $-0.075)$. However, there appears to be a positive relationship with work engagement for clinical teaching on seeking challenges in patient care, both when clinical teaching was combined only with patient care $(\beta=0.206,95 \% \mathrm{CI}$ : 0.031 to 0.381 ) and when combined with both teaching roles $(\beta=0.131,95 \%$ CI: 0.000 to 0.263$)$.

\section{Impact of being a resident versus being a medical specialist}

While medical specialists were more engaged for clinical teaching than residents were (mean 4.05 versus $3.64, p<$ 0.001 ), there were no difference for patient care and for classroom teaching.

However, in the structural equation model there appeared a stronger attempt from residents in seeking social resources in patient care $(ß=0.657,95 \%$ CI: 0.399 to 0.916 , for residents combining patient care with both teaching roles). For full details, see Table 6 .

Table 4 Effects of work engagement for both patient care, classroom and clinical teaching on job crafting in clinical teaching (bold indicates findings with $p<0.05)$, full cases

\begin{tabular}{|c|c|c|c|c|}
\hline \multirow{3}{*}{$\begin{array}{l}\text { Job crafting in } \\
\text { clinical teaching }\end{array}$} & \multicolumn{2}{|c|}{ Work engagement with patient care } & \multicolumn{2}{|c|}{ Work engagement with clinical teaching } \\
\hline & \multicolumn{2}{|l|}{ Combined with... } & \multicolumn{2}{|l|}{ Combined with... } \\
\hline & $\begin{array}{l}\ldots \text { only clinical } \\
\text { teaching }(N=80)\end{array}$ & $\begin{array}{l}\ldots \text { both teaching } \\
\text { roles }(N=267)\end{array}$ & $\begin{array}{l}\ldots \text { only patient } \\
\text { care }(N=80)\end{array}$ & $\begin{array}{l}\text {... classroom teaching } \\
\text { and patient care }(N=267)\end{array}$ \\
\hline & Std. coef. $(95 \%$ Cl) & Std. coef. $(95 \%$ Cl) & Std. coef. (95\% Cl) & Std. coef. $(95 \%$ Cl) \\
\hline Seeking social resources & $\beta-0.180(-0.366-0.006)$ & $\beta-0.015(-0.135-0.104)$ & В 0.341 (0.187-0.495) & В $0.183(0.088-0.279)$ \\
\hline Seeking structural resources & $\beta-0.072(-0.223-0.078)$ & $ß-0.148(-0.255--0.042)$ & B $0.379(0.252-0.506)$ & В $0.391(0.290-0.491)$ \\
\hline Seeking challenges & $\beta-0.194(-0.422-0.034)$ & $ß-0.190(-0.319--0.061)$ & В $0.361(0.138-0.583)$ & В $0.428(0.320-0.536)$ \\
\hline Avoiding hindrances & $\beta-0.113(-0.227-0.001)$ & $\beta-0.015(-0.088-0.059)$ & В $0.049(-0.014-0.111)$ & $\beta-0.056(-0.099--0.012)$ \\
\hline
\end{tabular}




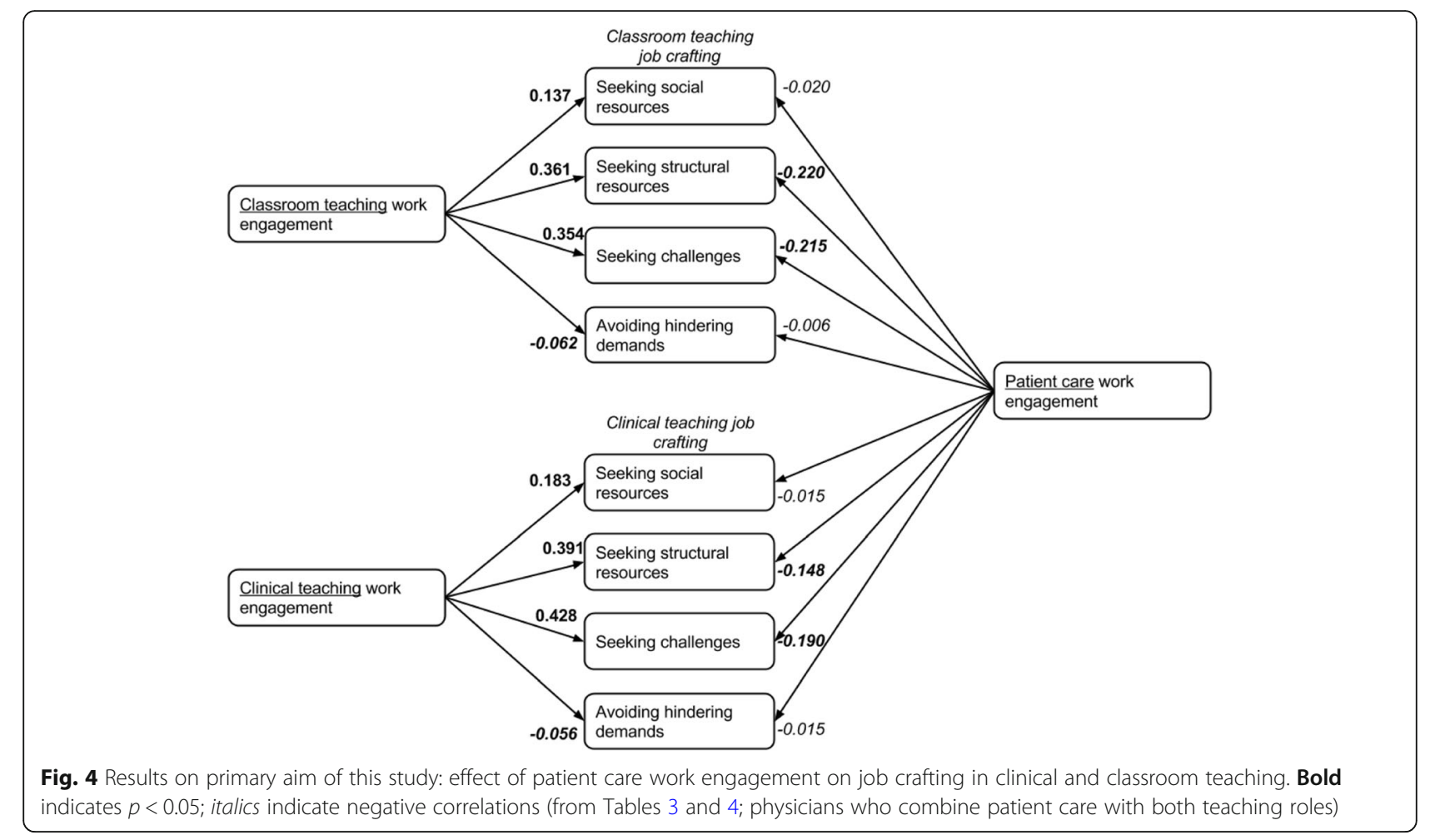

\section{Impact of autonomy and participation and decision making}

Overall, the impact of the two job resources 'autonomy' and 'participation in decision making' on work engagement was mostly positive. When work in patient care was combined with work in both teaching roles, 'participation in decision making' was significantly correlated to being engaged for patient care, classroom and clinical teaching: $\beta=0.229$ (95\% CI: 0.080 to 0.378 ), $ß=0.367$ (95\% CI: 0.194 to 0.539 ), $ß=0.314$ ( $95 \%$ CI: 0.148 to 0.480 ) respectively. Autonomy was significantly correlated to patient care work engagement: $\beta=0.163$ (95\% CI: 0.006 to 0.321 ). Autonomy was also correlated with work engagement for classroom teaching, but only when classroom teaching was combined with work in patient care: $\beta=0.379$ ( $95 \%$ CI: 0.037 to 0.721 ). The results for the correlation between resources in clinical teaching showed a similar pattern but were not statistically significant. The full results for the impact of autonomy and participation in decision making on job crafting can be found in Table 7.

Overall, fit measures of the entire model were poor. For the SEM-model for physicians with only classroom teaching CFI was 0.748 and RMSEA was 0.193; physicians with only clinical teaching CFI was 0.721 and RMSEA 0.206; physicians with both teaching roles CFI was 0.722 and RMSEA was 0.191.

\section{Discussion}

For faculty working in patient care, classroom teaching and/or clinical teaching, this study sought to investigate the relations between their work engagement and job crafting behaviours, both within each of the three

Table 5 Effects of work engagement for both patient care, classroom and clinical teaching on job crafting in patient care (bold indicates findings with $p<0.05)$, full cases

\begin{tabular}{|c|c|c|c|c|}
\hline \multirow{4}{*}{$\begin{array}{l}\text { Job crafting in } \\
\text { patient care }\end{array}$} & \multicolumn{2}{|c|}{ Work engagement with classroom teaching } & \multicolumn{2}{|c|}{ Work engagement with clinical teaching } \\
\hline & \multicolumn{2}{|l|}{ Combined with... } & \multicolumn{2}{|l|}{ Combined with... } \\
\hline & ... only patient care & $\begin{array}{l}\text {... clinical teaching } \\
\text { and patient care }\end{array}$ & $\ldots$ only patient care & $\begin{array}{l}\text {... classroom teaching } \\
\text { and patient care }\end{array}$ \\
\hline & Std. coef. $(95 \%$ Cl) & Std. coef. (95\% Cl) & Std. coef. (95\% Cl) & Std. coef. $(95 \%$ Cl) \\
\hline Seeking social resources & ß $-0.183(-0.407-0.041)$ & ß-0.016 (-0.089-0.057) & B $-0.122(-0.290-0.045)$ & В $0.048(-0.083-0.180)$ \\
\hline Seeking structural resources & ß $-0.113(-0.248-0.023)$ & $B-0.081(-0.160--0.002)$ & ß $-0.040(-0.144-0.064)$ & В $0.094(-0.029-0.216)$ \\
\hline Seeking challenges & $ß-0.236(-0.398--0.075$ & ß $-0.015(-0.103-0.073)$ & В $0.206(0.031-0.381)$ & В $0.131(0.000-0.263)$ \\
\hline Avoiding hindrances & B $-0.503(-0.749--0.258)$ & В $0.019(-0.020-0.058)$ & B $0.025(-0.084-0.134)$ & $\beta-0.034(-0.101-0.033)$ \\
\hline
\end{tabular}


Table 6 Effects of being a resident on job crafting subscales (versus being a medical specialist) on job crafting in classroom teaching, clinical teaching and patient care (bold indicates findings with $p<0.05$ ), full cases

\begin{tabular}{|c|c|c|c|}
\hline \multirow[t]{2}{*}{ Job crafting } & $\begin{array}{l}\text { Residents combining patient } \\
\text { care with classroom teaching }\end{array}$ & $\begin{array}{l}\text { Residents combining patient } \\
\text { care with clinical teaching }\end{array}$ & $\begin{array}{l}\text { Residents combining patient } \\
\text { care with both teaching roles }\end{array}$ \\
\hline & Std. coef. $(95 \%$ Cl) & Std. coef. (95\% CI) & Std. coef. $(95 \%$ Cl) \\
\hline \multicolumn{4}{|l|}{ Patient care } \\
\hline Seeking social resources & B $1.052(0.110-1.994)$ & В $0.837(0.403-1.272)$ & В $0.657(0.399-0.916)$ \\
\hline Seeking structural resources & $\beta-0.073(-0.722-0.577)$ & В $0.209(-0.169-0.588)$ & В $0.122(-0.060-0.303)$ \\
\hline Seeking challenging demands & B $0.571(-0.794-1.935)$ & $B-0.572(-1.021--0.123)$ & ß $0.087(-0.169-0.343)$ \\
\hline Avoiding hindering demands & B $1.125(-0.114-2.364)$ & ß $-0.054(-0.364-0.256)$ & B $0.064(-0.125-0.253)$ \\
\hline \multicolumn{4}{|l|}{ Classroom teaching } \\
\hline Seeking social resources & В $0.074(-0.791-0.938)$ & N/A & В $0.372(0.124-0.619)$ \\
\hline Seeking structural resources & В $-0.052(-0.888-0.784)$ & N/A & В 0.097 (- 0.149-0.343) \\
\hline Seeking challenging demands & В $0.848(-0.029-1.726)$ & N/A & В $0.270(0.014-0.525)$ \\
\hline Avoiding hindering demands & В $0.075(-0.415-0.565)$ & N/A & B $0.009(-0.214-0.231)$ \\
\hline \multicolumn{4}{|l|}{ Clinical teaching } \\
\hline Seeking social resources & N/A & В $0.097(-0.321-0.515)$ & В $0.098(-0.140-0.335)$ \\
\hline Seeking structural resources & N/A & ß $-0.225(-0.649-0.199)$ & ß $-0.077(-0.311-0.157)$ \\
\hline Seeking challenging demands & N/A & $\beta-0.368(-0.787-0.051)$ & В $0.177(-0.098-0.452)$ \\
\hline Avoiding hindering demands & N/A & B $0.044(-0.2070 .295)$ & $B-0.037(-0.245-0.170)$ \\
\hline
\end{tabular}

professional roles (intra-role) as well as between those roles (inter-role relations). We found positive intra-role relationships between work engagement and job crafting, thus high engagement for either patient care or teaching leads to job crafting in patient care or teaching. Yet, between roles, this relation was absent or even negative. Thus, faculty who were more engaged for patient care were worse at adjusting their work in teaching than those who were less engaged (inter-role).

We suggest the psychological processes underlying work engagement may explain these findings. First, considering the characteristics of work engagement (i.e. vigor, dedication and absorption), it could be argued that being highly engaged makes it more difficult to detach oneself from the patient care role to invest time and resources in classroom teaching and clinical teaching. A possible, positive side effect then may be that patient care work engagement protects against distractions from other responsibilities, ensuring patient safety and quality of care. Secondly, clinical faculty may simply not recognize the benefit of seeking resources across roles in favor of avoiding time investment altogether but the low scores on the 'avoiding hindering demands' make this reasoning less likely.

The positive correlation between clinical teaching work engagement and seeking challenges in patient care, despite the other findings, could imply work engagement leads to seeking challenges within and across roles.

Table 7 The impact of autonomy and participation in decision making on work engagement within roles (bold indicates findings with $p<0.05)$, full cases

\begin{tabular}{|c|c|c|c|}
\hline \multirow[t]{2}{*}{$\begin{array}{l}\text { Work engagement per } \\
\text { combination of roles }\end{array}$} & Autonomy & $\begin{array}{l}\text { Participation in decision } \\
\text { making (PiDM) }\end{array}$ & $\begin{array}{l}\text { Covariance between } \\
\text { autonomy and PiDM }\end{array}$ \\
\hline & Std. coef. (95\% Cl) & Std. coef. (95\% Cl) & Std. coef. (95\% Cl) \\
\hline Patient care, only with classroom teaching & ß $0.165(-0.272-0.602)$ & В $0.190(-0.222-0.602)$ & ß $0.434(0.279-0.590)$ \\
\hline Patient care, only with clinical teaching & В $0.347(-0.014-0.707)$ & В $0.112(-0.160-0.384)$ & В 0.589 (0.375-0.797) \\
\hline Patient care, with both teaching roles & B $0.163(0.006-0.321)$ & В $0.229(0.080-0.378)$ & B $0.534(0.435-0.632)$ \\
\hline Classroom teaching, with only patient care & В $0.379(0.037-0.721)$ & В $0.209(-0.173-0.590)$ & B 0.404 (0.195-0.613) \\
\hline $\begin{array}{l}\text { Classroom teaching, with clinical teaching } \\
\text { and patient care }\end{array}$ & В $0.182(-0.002-0.366)$ & В $0.367(0.194-0.539)$ & B $0.706(0.591-0.821)$ \\
\hline Clinical teaching, only with patient care & В $0.319(-0.041-0.679)$ & В $0.158(-0.126-0.442)$ & В $0.674(0.448-0.899)$ \\
\hline $\begin{array}{l}\text { Clinical teaching with classroom teaching } \\
\text { and patient care }\end{array}$ & В $0.148(-0.038-0.335)$ & ß $0.314(0.148-0.480)$ & B $0.602(0.503-0.702)$ \\
\hline
\end{tabular}


The finding that residents appear more inclined to seek social resources may result from seeking feedback being an element of social resources; residents are expected to seek feedback on their performance during residency training and this finding may reflect their intent to do so.

\section{Practical implications}

Our results show that a high level of work engagement in a certain role leads to job crafting in that same role. Institutions can enable their clinical faculty to become engaged by providing a supportive work environment for each separate role. On the hospital level this could be embedded in both faculty development or wellbeing programs. On team level this could be part of jointly designing the best possible work environment for each team member.

The negative effects of higher work engagement on job crafting in teaching adds to the growing body of literature suggesting support for clinical faculty requires organi zational changes and a personalized approach [30] and preferably equally across roles [19]. Separate career-tracks for clinician-educators have been advocated for decades [31], but these career-tracks aim to provide long term-support to those physicians who already chose to be an educator. Rather, we need to acknowledge that in current thinking on physician competence, being a (clinical) teacher is an integral part of any physician's daily work and many will not be able to adapt their work to fully meet their needs in all roles.

We have shown that providing autonomy and the opportunity to participate in decision making may boost engagement equally for patient care and teaching. In addition, it may be beneficial to provide clinical faculty with opportunities for professional development and provide them with feedback on their teaching performance [5], as has been suggested before [32]. A different approach could be to ensure teachers have the opportunity to connect with like-minded educators, to enable them to connect and tap into social resources informally [33]. To add to this, interventions specifically aimed at job crafting may be considered [34].

Lastly, we found intra-class correlation for hospitals to be low on both work engagement and job crafting subscales. This suggests support needs to be initiated at a lower organizational level, such as the department or more likely according to individual needs [20].

\section{Strengths and limitations}

The main strength of this study is its multicenter design. This has increased generalizability and allowed us to assess variance within and between hospitals. In addition, the transformation from the physician as solely a provider of care to a medical professional who is expected to show competence in multiple roles is a global trend and tension between academic roles appears universal.

The main limitation of this study is its cross-sectional design. While it is known that work engagement and job crafting affect each other cyclically throughout time, its relation within and across roles have so far remained unstudied in this context. We consider this cross-sectional study as a necessary step towards a longitudinal design. Furthermore, the convenience sampling method leads to some uncertainty towards representativeness of our sample. Our sample is consciously diverse and this leads to wide ranges on all included variables and a wide variety in participants' backgrounds. As such our findings may turn out to be more nuanced in specific populations within the medical education context.

Lastly, while exact response rates were unknown, there is a risk for nonresponse or selection bias. Several findings suggest there is a low risk these biases would strongly affect our outcomes. Baseline characteristics did not differ significantly between centers with a lower or higher absolute response on work engagement and job crafting. In addition, our work engagement scores and their distribution across roles is consistent with previous research [9,35]. Furthermore, considering the consistent findings across subgroups, it is conceivable that more extreme responses would more likely inflate coefficients without essentially changing the negative correlation between work engagement and job crafting between roles. However, it will be important in future research to decrease this uncertainty by replicating our findings, aiming for high response rate and where possible accounting for nonresponse bias for instance by using the nonresponse bias analysis method [36].

\section{Future research}

The broader topic of understanding how to best support clinical faculty may benefit from qualitative approaches. Quantitative approaches may not capture the intricacies as work engagement and job crafting depend highly on interaction between individuals and interaction with the work environment. Qualitative approaches are especially suitable for gaining a deeper understanding of the underlying mechanisms, as noted in another journal recently [37]. Any longitudinal studies on either burnout or work engagement should consider job crafting as a variable in their statistical analysis.

\section{Conclusion}

When physicians experience high levels of work engagement towards patient care, they seem less inclined to modify their teacher tasks. For job crafting in teaching (both classroom and clinical) to occur, engagement for teaching appears a prerequisite. Role-specific job crafting interventions may be necessary to provide adequate support for the role of teacher. 


\section{Additional file}

Additional file 1: Table S1. a - Effects of work engagement for both patient care, classroom and clinical teaching on job crafting in classroom teaching (bold indicates findings with $p<0.05$ ), imputed cases. Table S1. $\mathrm{b}$ - Effects of work engagement for both patient care, classroom and clinical teaching on job crafting in clinical teaching, imputed cases. Table S2. Effects of work engagement for patient care on job crafting within patient care. Table S3. The impact of autonomy and participation in decision making on work engagement within roles, imputed cases. (DOC $76 \mathrm{~kb})$

\section{Abbreviations}

CFI: Confirmatory Fit Index; Cl: Confidence Interval; ICC: Intra-class correlation; JC: Job crafting; RMSEA: Root Mean Square Error of Approximation; SEM: Structural Equation Model; UWES-9 : Utrecht Work Engagement Scale-9; WE: Work Engagement

\section{Acknowledgements}

Collaborators: We wish to acknowledge, in alphabetical order, the following collaborators for substantial contributions and their indispensable support during data collection at the various participating hospitals. No additional compensation was provided.

Professor Paul LP Brand MD PhD, princess Amalia Children's Center, Isala Hospital, Zwolle, the Netherlands and UMCG Postgraduate School of Medicine, University Medical Center and University of Groningen, the Netherlands.

Lia CRMG Fluit MD PhD MEd, Radboudumc Health Academy Nijmegen. Professor Ide C Heyligers MD PhD, Zuyderland MC Teaching Hospital, Maastricht University-School of Health Professions Education Maastricht. Paetrick M Netten MD PhD, Jeroen Bosch Hospital, 's Hertogenbosch. Rob J Oostenbroek MD PhD, Department of Education, Albert Schweitzer hospital, Dordrecht.

Jelle T Prins PhD, MCL Academy, Medical Center Leeuwarden, Leeuwarden. Professor Frank WJM Smeenk MD PhD, Catharina-hospital, Eindhoven

\section{Author contributions}

Study concept and design: JvdB, CV, DJ, AS, KL. Acquisition of data: JvdB, CV, DJ, AS, KL. Analysis and interpretation of data: JvdB, CV, DJ, AS, OA, KL.

Statistical analysis: JvdB, OA. Drafting of the manuscript: JvdB. Critical revision of the manuscript for important intellectual content: JvdB, CV, DJ, AS, OA, KL. All authors confirmed final approval of submission and agree to be accountable for all aspects of the work in ensuring that questions related to the accuracy or integrity of any part of the work are appropriately investigated and resolved.

\section{Funding}

No additional monetary support was used for this study.

\section{Availability of data and materials}

The datasets generated and/or analysed during the current study are not publicly available due limitations contained in the informed consent form on data availability but are available from the corresponding author on reasonable request.

\section{Ethics approval and consent to participate}

Ethical approval was obtained through the Dutch Association for Medical Education Ethical Review Board under dossier number 385. Participant consent was written (in digital form) and without consent participation in the online survey was impossible.

\section{Consent for publication}

Not applicable.

\section{Competing interests}

The authors declare that they have no competing interests.

\section{Publisher's Note}

Springer Nature remains neutral with regard to jurisdictional claims in published maps and institutional affiliations.

\section{Author details}

${ }^{1}$ Professional Performance research group, Department of Medical Psychology, Academic Medical Center (AMC-UvA), Meibergdreef 15, 1105AZ Amsterdam, the Netherlands. ${ }^{2}$ ICLON, Leiden University Graduate School of Teaching, Leiden, the Netherlands. ${ }^{3}$ Faculty of Health, Medicine and Life Sciences, Maastricht University, Maastricht, the Netherlands. ${ }^{4}$ Center for Research \& Innovation in Medical Education, University Medical Center Groningen, University of Groningen, Groningen, The Netherlands. ${ }^{5}$ Department of Epidemiology, UCLA Fielding School of Public Health, Los Angeles, California, USA

Received: 1 November 2017 Accepted: 29 November 2018

Published online: 19 December 2018

\section{References}

1. West CP, Shanafelt TD, Kolars JC. Quality of life, Burnout, educational debt, and medical knowledge among internal medicine residents. JAMA. 2011; 306:350-2 Available from: https://www.ncbi.n/m.nih.gov/pubmed/21900135.

2. Shanafelt TD, West CP, Sloan JA, Novotny PJ, Poland GA, Menaker R, et al. Career fit and burnout among academic faculty. Arch Intern Med. 2009:169: 990-5 Available from: http://www.ncbi.nlm.nih.gov/pubmed/19468093.

3. Dyrbye LN, West CP, Satele D, Boone S, Tan L, Sloan J, et al. Burnout Among U.S. Medical Students, Residents, and Early Career Physicians Relative to the General U.S. Population. Acad Med. 2014;89:443-51 Available from: http:// www.ncbi.nlm.nih.gov/pubmed/24448053 [cited 26 Feb 2014].

4. Prins JT, Gazendam-Donofrio SM, Tubben BJ, van der Heijden FMMA, van de Wiel HBM, JEHM H-W. Burnout in medical residents: a review. Med Educ. 2007;41:788-800 Available from: http://www.ncbi.nlm.nih.gov/pubmed/ 17661887 [cited 1 Oct 2014].

5. Bakker AB. An Evidence-Based Model of Work Engagement. Curr Dir Psychol Sci. 2011;20:265-9 Available from: http://cdp.sagepub.com/lookup/doi/10. 1177/0963721411414534 [cited 2012 Oct 3]

6. Bakker AB, Demerouti $E$. The job demands-resources model: state of the art. J Manag Psychol. 2007;22:309-28 Available from: http://www. emeraldinsight.com/doi/10.1108/02683940710733115.

7. Korunka C, Kubicek B, Schaufeli WB, Hoonakker P. Work engagement and burnout: testing the robustness of the Job Demands-Resources model. J Posit Psychol. 2009;4:243-55 Available from: http://www.tandfonline.com/ doi/abs/10.1080/17439760902879976 [cited 12 Oct 2012].

8. Scheepers RA, Boerebach BCM, Arah OA, Heineman MJ, Lombarts KMJMH. A systematic review of the impact of physicians' occupational well-being on the quality of patient care. Int J Behav Med. 2015;22:683-98 Available from: http://link.springer.com/10.1007/s12529-015-9473-3.

9. Scheepers RA, Arah OA, Heineman MJ, KMJMH L. In the eyes of residents good supervisors need to be more than engaged physicians: the relevance of teacher work engagement in residency training. Adv Heal Sci Educ. 2014; 20:441-55 Available from: http://www.ncbi.n/m.nih.gov/pubmed/25118859 [cited 14 Oct 2014].

10. Schaufeli WB, Salanova M, González-Romá V, Bakker AB. The measurement of engagement and burnout: A two sample confirmatory factor analytic approach. J Happiness Stud. 2002;3:71-92 Available from: http://www. springerlink.com/index/HC82G16YTW7FJ728.pdf [cited 15 Oct 2012].

11. Maslach C, Schaufeli WB, Leiter MP. Job burnout. Annu Rev Psychol. 2001;52: 397-422.

12. Bakker AB, Hakanen JJ, Demerouti E, Xanthopoulou D. Job resources boost work engagement, particularly when job demands are high. J Educ Psychol. 2007;99:274-84 Available from: http://doi.apa.org/getdoi.cfm?doi=10.1037/ 0022-0663.99.2.274 [cited 12 Oct 2012].

13. Tims M, Bakker AB. Job crafting: Towards a new model of individual job redesign. SA J Ind Psychol. 2010;36:1-9. Available from: http://sajip.co.za/ index.php/sajip/article/view/841 [cited 2 Apr 2014].

14. Tims M, Bakker AB, Derks D. The impact of job crafting on job demands, job resources, and well-being. J Occup Health Psychol. 2013;18:230-40 Available from: http://www.ncbi.nlm.nih.gov/pubmed/23506549 [cited 17 Jul 2014].

15. Gordon HJ, Demerouti E, Le Blanc PM, Bipp T. Job crafting and performance of Dutch and American Health care professionals. J Pers Psychol. 2015;14: 
192-202 Available from: https://econtent.hogrefe.com/doi/abs/10.1027/ 1866-5888/a000138?journalCode=pps.

16. Hakanen JJ, Perhoniemi R, Toppinen-Tanner S. Positive gain spirals at work: From job resources to work engagement, personal initiative and work-unit innovativeness. J Vocat Behav. 2008;73:78-91 Available from: http://linkinghub. elsevier.com/retrieve/pii/S0001879108000110 [cited 11 Nov 2012].

17. Bakker A, Tims M, Derks D. Proactive personality and job performance: The role of job crafting and work engagement. Hum Relations. 2012;65:1359-78 Available from: http://hum.sagepub.com/cgi/doi/10.1177/ 0018726712453471 [cited 2014 Jul 17].

18. Kumar K, Roberts C, Thistlethwaite J. Entering and navigating academic medicine: academic clinician-educators' experiences. Med Educ. 2011;45:497-503.

19. Pololi LH, Krupat E, Civian JT, Ash AS, Brennan RT. Why Are a Quarter of Faculty Considering Leaving Academic Medicine? A Study of Their Perceptions of Institutional Culture and Intentions to Leave at 26 Representative U.S. Medical Schools. Acad Med. 2012;87:859-69 Available from: http://www.ncbinlm.nih.gov/pubmed/22622213 [cited 31 May 2012]

20. van den Berg JW, Verberg CPM, Berkhout JJ, Lombarts MJMH, Scherpbier AJJA, Jaarsma ADC. A qualitative interview study on the positive well-being of medical school faculty in their teaching role: job demands, job resources and role interaction. BMC Res Notes. 2015;8:401 Available from: http://www. biomedcentral.com/1756-0500/8/401.

21. Tims $M, B a k k e r ~ A B$, Derks D. Development and validation of the job crafting scale. J Vocat Behav. 2012;80:173-86 Available from: http://linkinghub. elsevier.com/retrieve/pii/S0001879111000789 [cited 15 Aug 2013].

22. Schaufeli WB, Bakker AB, Salanova M. The Measurement of Work Engagement With a Short Questionnaire: A Cross-National Study. Educ Psychol Meas. 2006;66:701-16 Available from: http://epm.sagepub.com/ content/66/4/701.short [cited 12 Nov 2012].

23. Van Veldhoven M, De Jonge J, Broersen S, Kompier M, Meijman T. Specific relationships between psychosocial job conditions and job-related stress: A threelevel analytic approach. Work Stress. 2002;16:207-28 Available from: http://www. tandfonline.com/doi/abs/10.1080/02678370210166399 [cited 5 Mar 2013].

24. Prins JT, van der Heijden FMMA, Hoekstra-Weebers JEHM, Bakker AB, van de Wiel HBM, Jacobs B, et al. Burnout, engagement and resident physicians' self-reported errors. Psychol Health Med. 2009;14:654-66 Available from: http://www.ncbi.nlm.nih.gov/pubmed/20183538 [cited 2 Sep 2013].

25. Graham JW, Olchowski AE, Gilreath TD. How many imputations are really needed? Some practical clarifications of multiple imputation theory. Prev Sci. 2007:8:206-13.

26. R Core Team. R: a language and environment for statistical computing. Vienna, Austria: R Foundation for statistical Computing; 2015.

27. Rosseel Y. Lavaan: an R package for structural equation modeling. J Stat Softw. 2012;48:1-36

28. semTools Contributors. semTools: Useful tools for structural equation modeling [Internet]. 2016. Available from: http://cran.r-project.org/package= semTools

29. Buuren S van, Groothuis-Oudshoorn K. Mice : Multivariate Imputation by Chained Equations in R. J. Stat. Softw. 2011;45:1-67. Available from: http:// www.jstatsoft.org/v45/i03/

30. Shanafelt TD. Enhancing Meaning in Work: A Prescription for Preventing Physician Burnout and Promoting Patient-Centered Care. JAMA. 2009;302: 1338 Available from: http://jama.jamanetwork.com/article.aspx?doi=10.1001/ jama.2009.1385.

31. Fleming V, Schindler N, Martin G, DaRosa D. Separate and equitable promotion tracks for clinician-educators. JAMA. 2005;294:1 101-4 Available from: http://archinte.jamanetwork.com/article.aspx?articleid=201467 [cited 23 Apr 2014].

32. Lowenstein SR, Fernandez G, Crane LA. Medical school faculty discontent: prevalence and predictors of intent to leave academic careers. BMC Med Educ. 2007;7:37 Available from: http://www.pubmedcentral.nih.gov/ articlerender.fcgi?artid $=2194670 \&$ tool $=$ pmcentrez\&rendertype $=$ abstract [cited 1 Oct 2014].

33. van den Berg JW, Verberg CP, Scherpbier AJ, Jaarsma DA, Lombarts KM. Is being a medical educator a lonely business? Accepted: The essence of social support; 2016

34. Van Wingerden J, Derks D, Bakker AB. The Impact of Personal Resources and Job Crafting Interventions on Work Engagement and Performance. Hum Resour Manage. 2015;45 n/a-n/a. Available from: http://doi.wiley.com/10.1002/hrm.21758.

35. van den Berg BAM, Bakker AB, Ten Cate TJ. Key factors in work engagement and job motivation of teaching faculty at a university medical centre.
Perspect Med Educ. 2013;2:264-75 Available from: http://www. pubmedcentral.nih.gov/articlerender.fcgi?artid=3824746\&tool= pmcentrez\&rendertype=abstract [cited 17 Dec 2013].

36. Thompson CA, Arah OA. Selection bias modeling using observed data augmented with imputed record-level probabilities. Ann Epidemiol Elsevier Inc. 2014;24:747-53.

37. Greenhalgh T, Annandale E, Ashcroft R, Barlow J, Black N, Bleakley A, et al. An open letter to The BMJ editors on qualitative research. BMJ. 2016; i563. Available from: http://www.bmj.com/lookup/doi/10.1136/bmj.i563.

\section{Ready to submit your research? Choose BMC and benefit from:}

- fast, convenient online submission

- thorough peer review by experienced researchers in your field

- rapid publication on acceptance

- support for research data, including large and complex data types

- gold Open Access which fosters wider collaboration and increased citations

- maximum visibility for your research: over $100 \mathrm{M}$ website views per year

At BMC, research is always in progress.

Learn more biomedcentral.com/submissions 